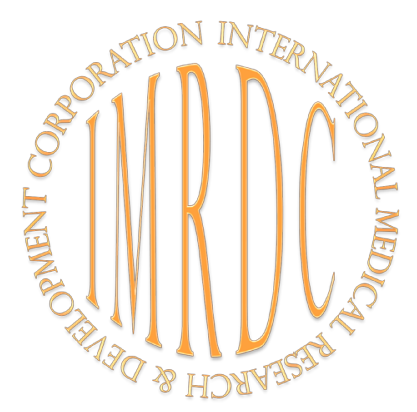

International Journal of Biomedicine 5(4) (2015) 203-206

doi: 10.21103/Article5(4)_OA7

ORIGINAL ARTICLE

Cardiology

INTERNATIONAL

JOURNAL

OF BIOMEDICINE

\title{
Effectiveness of Personalized Therapy in Elderly Patients with Isolated Systolic Hypertension
}

\author{
E.A. Kartashova, $\mathrm{PhD}^{1}$; I.V. Sarvilina, $\mathrm{PhD}, \mathrm{ScD}^{2}$ \\ ${ }^{1}$ Rostov-on-Don State Medical University \\ ${ }^{2}$ Medical Centre "Novomeditsina" \\ Rostov-on-Don, the Russian Federation
}

\begin{abstract}
The purpose of this study was the development of personalized modes of therapy in elderly patients with isolated systolic hypertension (ISH).

The study included 306 persons divided into two groups: Group 1 (Control) included 150 elderly persons without arterial hypertension (AH), and Group 2 included 256 elderly patients (early old-age pension, between 65 and 74 years) with ISH (ESH/ ESC,2013) according to the inclusion/exclusion criteria. All patients of Group 2 were divided into three subgroups depending on the combination of drugs at the beginning of the study. Group 2a $(\mathrm{n}=53)$ received amlodipine $(5 \mathrm{mg} /$ day) and indapamide-retard $(1.5 \mathrm{mg} /$ day $)$, Group $2 \mathrm{~b}(\mathrm{n}=53)$ received valsartan $(80 \mathrm{mg} /$ day $)$ and indapamide-retard $(1.5 \mathrm{mg} /$ day $)$, and Group $2 \mathrm{c}(\mathrm{n}=50)$ received amlodipine $(5 \mathrm{mg} /$ day) and valsartan $(80 \mathrm{mg} /$ day). The duration of therapy was 5.2 years.

At the stage of data collection and screening, we applied standard methods for identification of ISH and secondary hypertension. Molecular phenotyping of blood serum was performed with methods of proteomics. We obtained the data of the molecular interactions and functional features of proteins from the STRING 10.0 database.

Proteomic analysis contributes to the development of a personalized mode treatment in ISH patients, which is the safest and most efficient: 135 ISH patients switched to the administration of the amlodipine+valsartan combination. (Int $\mathbf{J}$ Biomed. 2015;5(4):203-206.)
\end{abstract}

Keywords: isolated systolic hypertension; personalized therapy; proteomics; bioinformatics; molecular interactions.

\section{Introduction}

The purpose of this study was the development of personalized modes of therapy in elderly patients with isolated systolic hypertension (ISH).

Currently, arterial hypertension (AH) is often defined as accelerated aging. Aging has a pronounced effect on the cardiovascular system, largely involving vessels (vascular aging). Aging is associated with the development of the remodeling processes in the cardiovascular system [1-3]. Experimental and clinical trials have shown that myocardial contractility and stiffness of vascular walls are vulnerable to age-related changes [3]. A molecular map of aging in the cardiovascular system of elderly patients, accompanied by the emergence of $\mathrm{AH}$, cannot be described only on the basis of standard methods of clinical research.

*Corresponding author: Irina V. Sarvilina, PhD, ScD. CEO of Medical Centre «Novomeditsina», Rostov-on-Don, Russian Federation..E-mail: isarvilina@mail.ru
Modern methods and technologies of molecular analysis of large interactomes (blood, urine) and human tissues (myocardium, vascular wall) - including methods of genomics, transcriptomics, proteomics, and metabolomicsallow us to explore pathways of aging of target organs in elderly AH patients.

According to multicenter studies, modern hypotensive drugs indirectly eliminate remodeling processes in the myocardium and vascular walls, mainly by reducing systolic and diastolic blood pressure (BP). Today we need progress in the development and clinical application of the hypotensive drugs which impact key genomic-epigenomic interactions underlying the aging processes of the cardiovascular system, taking into account the results of population studies.

\section{Materials and Methods}

To address this need, we conducted a comparative prospective cohort study with parallel design. The study included 306 persons divided into two groups: Group 1 
(Control) included 150 elderly persons without $\mathrm{AH}$, and Group 2 included 256 elderly patients (early old-age pension, between 65 and 74 years) with ISH, according to the inclusion/ exclusion criteria. Patients with ISH corresponded to the criteria for the classification of BP levels (SBP $>140 \mathrm{mmHg}$ and $\mathrm{DBP}<90 \mathrm{mmHg})$ and risk stratification - middle $(\mathrm{n}=87)$ and high $(n=69)$ additional risk proposed by the ESH/ESC (2013) Guidelines for the management of arterial hypertension [4]. ISH duration was 13.5 years. All patients of Group 2 were divided into three subgroups depending on the combination of drugs [(amlodipine (calcium antagonist), indapamide-retard (diuretic), and valsartan (angiotensin receptor blocker)] at the beginning of the study.

Group 2a $(\mathrm{n}=53)$ received amlodipine $(5 \mathrm{mg} /$ day $)$ and indapamide-retard $(1.5 \mathrm{mg} /$ day $)$, Group $2 \mathrm{~b}(\mathrm{n}=53)$ received valsartan $(80 \mathrm{mg} /$ day $)$ and indapamide-retard $(1.5 \mathrm{mg} /$ day $)$, and Group $2 \mathrm{c}(\mathrm{n}=50)$ received amlodipine $(5 \mathrm{mg} /$ day $)$ and valsartan $(80 \mathrm{mg} /$ day $)$. The duration of therapy was 5.2 years. The subgroups were matched for age, sex, SIH Grades, middle/high additional risk stratification, and disease duration. The antihypertensive efficacy of different treatment regimes was evaluated by the BP decrease (more than 15\%) and achievement of target BP.

At the stage of data collection and screening, we applied standard methods for identification of ISH and secondary hypertension: the assessment of the patient's complaints, medical history, physical examination, 24-hour ABPM, ECG (ATES MEDICA, Italy-Russia), echocardiography (SamsungMedison, South Korea), blood and urine tests, biochemical analysis of blood and urine, blood level of aldosterone and corticosteroids, plasma renin activity, urinary catecholamines and metabolites (ELISA, Siemens 2000, Germany), coagulogram («Instrumentation Laboratory», USA), and an MRI of adrenal glands, kidney and brain (Philips Intera 1.5T, Japan).

Molecular phenotyping of blood serum was performed with methods of proteomics: the prefractionation, the separation of proteins with standard sets (MB-HIC C8 Kit, MB-IMAC $\mathrm{Cu}, \mathrm{MB}-W a x$ Kit, «Bruker», USA), and the matrix-assisted, laser desorption-ionization, time-of-flight mass spectrometry (MALDI-TOF-MS/MS, Ultraflex II, «Bruker», USA). The partially identified sequences were then submitted to "BLAST protein-protein" and screened against the Homo sapiens Swissprot database to check whether this identification matched the MASCOT-identification (Matrix Science). We obtained the data of the molecular interactions and functional features of proteins from the STRING 10.0 database.

Based on the data of standard methods of identification of ISAH and molecular phenotyping of blood serum, we conducted a personalized selection of hypotensive drug therapy for each patient. After 3 years of personalized hypotensive drug therapy, parameters of standard methods and molecular phenotyping of blood serum were measured.

The study was conducted in accordance with ethical principles of the Declaration of Helsinki and approved by the Rostov-on-Don State Medical University Ethics Committee. Written informed consent was obtained from each patient.

Statistical analysis was performed using the statistical software «Statistica $12.0 »$. A probability value of $\mathrm{P}<0.05$ was considered statistically significant.

\section{Results}

Among Group 2 patients, Grade 1(n=48), Grade $2(n=82)$, and Grade $3(n=26)$ of SIH were identified (Table 1$)$. MRI signs of leukoaraiosis were detected in all patients with ISAH.

Table 1.

Clinical and anamnestic characteristics of ISH patients

\begin{tabular}{|c|c|c|c|}
\hline Parameter & $\begin{array}{c}\text { Group } 2 \mathrm{a} \\
(\mathrm{n}=53)\end{array}$ & $\underset{(\mathrm{n}=53)}{\text { Group } 2 \mathrm{~b}}$ & $\begin{array}{c}\text { Group } 2 \mathrm{c} \\
(\mathrm{n}=50)\end{array}$ \\
\hline Sex (male/female), $\mathrm{n}$ & $34 / 19$ & $33 / 20$ & $27 / 23$ \\
\hline Age, years & $69.2 \pm 2.9$ & $67.3 \pm 2.5$ & $68.2 \pm 2.8$ \\
\hline Weight, kg & $66.7 \pm 1.3$ & $69.4 \pm 1.6$ & $68.5 \pm 1.5$ \\
\hline Height, cm & $170.3 \pm 1.9$ & $167.5 \pm 1.3$ & $169.5 \pm 1.5$ \\
\hline $\mathrm{BMI}, \mathrm{kg} / \mathrm{m}^{2}$ & $19.6 \pm 1.2$ & $20.8 \pm 1.3$ & $22.0 \pm 1.5$ \\
\hline Duration of disease, years & $12.3 \pm 1.5$ & $15.7 \pm 1.9$ & $14.2 \pm 1.8$ \\
\hline Hypertensive crises, $\mathrm{n}$ & 16 & 11 & 7 \\
\hline $\begin{array}{l}\text { Risk factors: } \\
\text { Heredity } \\
\text { AH } \\
\text { CHD } \\
\text { Dyslipoproteinemia } \\
\text { Anamnesis } \\
\text { CVD } \\
\text { Dyslipoproteinemia } \\
\text { Smoking } \\
\text { Poor nutrition } \\
\text { Obesity } \\
\text { Low physical activity }\end{array}$ & $\begin{array}{c}25 \\
34 \\
11 \\
22 \\
- \\
25\end{array}$ & $\begin{array}{c}27 \\
34 \\
8 \\
13 \\
- \\
23\end{array}$ & $\begin{array}{c}35 \\
35 \\
35 \\
\\
25 \\
35 \\
10 \\
17 \\
- \\
25\end{array}$ \\
\hline $\begin{array}{l}\text { Target organs and associated } \\
\text { clinical conditions: } \\
\text { Brain and eyes (headache, } \\
\text { dizziness, impairment of view, } \\
\text { speech, TIA, sensory and motor } \\
\text { disorders) } \\
\text { Heart (heartbeat, pain in } \\
\text { the chest, shortness of breath, } \\
\text { swelling) } \\
\text { Kidney (thirst, polyuria, } \\
\text { nocturia, hematuria, swelling) } \\
\text { Peripheral arteries (cold } \\
\text { extremities, intermittent } \\
\text { claudication) }\end{array}$ & $\begin{array}{l}4 \\
5\end{array}$ & $\begin{array}{l}34 \\
5 \\
8\end{array}$ & $\begin{array}{c}35 \\
5 \\
7\end{array}$ \\
\hline $\begin{array}{l}\text { Physical examination: } \\
\text { Vascular changes in the fundus } \\
\text { Heart (offset heart borders, } \\
\text { arrhythmia, CHF) } \\
\text { Peripheral arteries (pulse } \\
\text { weakening or disappearance, } \\
\text { asymmetrical radial pulse, cold } \\
\text { extremities, symptoms of skin } \\
\text { ischemia) } \\
\text { Carotid arteries (systolic } \\
\text { murmur) }\end{array}$ & $\begin{array}{c}34 \\
34 \\
8\end{array}$ & $\begin{array}{l}34 \\
34 \\
13\end{array}$ & $\begin{array}{c}35 \\
35 \\
9\end{array}$ \\
\hline $\begin{array}{l}\text { ECG data: } \\
\text { Sokolov - Lyon index } \\
\text { (SV1+RV5-6) }>3.5 \mathrm{mV}, \mathrm{n} \\
\text { Cornell voltage QRS duration } \\
\text { product }(>244 \mathrm{mV} * \mathrm{~ms}), \mathrm{n}\end{array}$ & $\begin{array}{l}34 \\
34\end{array}$ & $\begin{array}{l}34 \\
34\end{array}$ & $\begin{array}{l}35 \\
35\end{array}$ \\
\hline
\end{tabular}

BMI-body mass index, CHD - coronary heart disease; TIA - transient ischemic attack; $C H F$ - chronic heart failure. 
At the stage of data collection and screening, we detected intergroup differences between indicators of 24-h daytime and nighttime SBP and DBP and heart rate in ISH patients taking 3 modes of hypotensive therapy. We revealed a significant reduction of these parameters in Group 2c compared to similar indicators in Groups 2a and 2b.

Daytime SBP: $141.2 \pm 3.4 \mathrm{mmHg}(2 \mathrm{a}), 138.3 \pm 3.6 \mathrm{mmHg}$ (2b), and $117.6 \pm 3.5 \mathrm{mmHg}(2 \mathrm{c}), P 2 a / 2 c<0.001, P 2 b / 2 c<0.001$;

Daytime DBP: $78.4 \pm 1.6 \mathrm{mmHg}(2 \mathrm{a}), 73.5 \pm 1.3 \mathrm{mmHg}$ (2b), and 69.4 $\pm 2.4 \mathrm{mmHg}(2 \mathrm{c}), P 2 a / 2 c<0.001, P 2 b / 2 c<0.01$;

Nighttime SBP: $130.9 \pm 3.6 \mathrm{mmHg}(2 \mathrm{a}), 127.4 \pm 3.2 \mathrm{mmHg}$ (2b), and $117.6 \pm 2.9 \mathrm{mmHg}(2 \mathrm{c}), P 2 a / 2 c<0.001, P 2 b / 2 c<0.001$;

Nighttime DBP: $81.8 \pm 1.4 \mathrm{mmHg}(2 \mathrm{a}), 75.4 \pm 1.2 \mathrm{mmHg}$ (2b), and $67.6 \pm 1.8 \mathrm{mmHg}(2 \mathrm{c}), P 2 a / 2 c<0.001, P 2 b / 2 c<0.01$;

Heart rate: $84.5 \pm 1.5 \mathrm{bpm}(2 \mathrm{a}), 77.2 \pm 1.8 \mathrm{bpm}(2 \mathrm{~b})$, and $72.3 \pm 1.2 \mathrm{bpm}$ (2c), $P 2 a / 2 c<0.001, P 2 b / 2 c<0.01$.

The downward trend of LVMI $\left[139.5 \pm 4.7 \mathrm{~g} / \mathrm{m}^{2}(2 \mathrm{a})\right.$, $137.3 \pm 4.3 \mathrm{~g} / \mathrm{m}^{2}(2 \mathrm{~b})$, and $129,4 \pm 3,9 \mathrm{~g} / \mathrm{m}^{2}(2 \mathrm{c}), \mathrm{P} 2 \mathrm{a} / 2 \mathrm{c}<0.001$, $\mathrm{P} 2 \mathrm{~b} / 2 \mathrm{c}<0.05$ ] was observed in patients taking the combination of amlodipine and valsartan.

Proteomic analysis helped in the detection of differences in the component composition of the serum proteins in ISH patients with varying grades who were taking different modes of hypotensive therapy, compared to Group 1 (Table 2).
Proteomic analysis contributes to the development of a personalized mode treatment in ISH patients, which is the safest and most efficient: 135 ISH patients switched to the administration of the amlodipine+valsartan combination. After 3 years of personalized hypotensive drug therapy, we identified a significant decrease in parameters of daytime/nighttime SBP and DBP, daily indexes, heart rate and of the myocardial performance index, as well as signs of the progression of ischemic, distrophic, metabolic, and morphogenetic disorders in the cardiovascular system in accordance with changes of peptide indicators in patients of Group 2c.

Bioinformatics analysis revealed the presence of molecules that are the participants in the universal pathways of cardivascular aging and the molecular interactions involved.

\section{Discussion}

Proteomic analysis revealed an increase in the absolute number of ISH patients with an abnormal profile of serum proteins performing certain biological functions and having various localizations in the intra- and extracellular spaces (Table 2). Molecules interact among themselves and with other molecules as participants in universal pathways in cardivascular aging in ISH patients: RAAS (renin-

Table 2

Qualitative profile of serum proteins in elderly ISH patients and control group

\begin{tabular}{|c|c|c|c|c|c|c|c|c|c|c|}
\hline № & Protein name & \multicolumn{7}{|c|}{ Number of patients with the expression of the serum protein $(\mathrm{n})$} & $\begin{array}{l}\mathrm{MW}^{*} \\
(\mathrm{Da})\end{array}$ & $\begin{array}{c}\text { Functional process } \\
\text { (sources: InterPro, Entrez, SWISS- } \\
\text { PROT, NRDB,, PDB, KEGG) }\end{array}$ \\
\hline 1 & $\begin{array}{l}\text { Disheveled- } \\
\text { associated activator of } \\
\text { morphogenesis } 1\end{array}$ & 23 & 53 & 8 & 53 & 7 & 50 & 28 & 123396 & $\begin{array}{l}\text { Epidermal cell proliferation, and } \\
\text { glucose and lipid metabolism }\end{array}$ \\
\hline 2 & Apolipoprotein D & 138 & 12 & 3 & 15 & 2 & 35 & 114 & 21262 & Fatty acid and steroid metabolism \\
\hline 3 & Brain spectrin & 144 & 22 & 6 & 19 & 7 & 34 & 108 & 41404 & $\begin{array}{l}\text { Cytoskeletal protein, } \\
\text { neurotransmission, neuromuscular } \\
\text { junction }\end{array}$ \\
\hline 5 & Neprilysin & 10 & 22 & 10 & 23 & 8 & 27 & 14 & 85460 & $\begin{array}{l}\text { Amyloid beta regulation, } \\
\text { the regulation of signaling peptides }\end{array}$ \\
\hline 6 & $\begin{array}{l}\text { Gamma butyrobetaine } \\
\text { hydroxylase }\end{array}$ & 145 & 22 & 3 & 33 & 6 & 45 & 130 & 44687 & $\begin{array}{l}\text { L-carnitine biosynthesis pathway, } \\
\text { mitochondrial beta oxidation }\end{array}$ \\
\hline 9 & Angiotensinogen & 3 & 12 & 3 & 9 & 3 & 10 & 1 & 53154 & $\begin{array}{l}\text { Blood pressure, body fluid and } \\
\text { electrolyte homeostasis }\end{array}$ \\
\hline 10 & $\begin{array}{l}\text { Hypoxia inducible } \\
\text { factor } 1\end{array}$ & 129 & 23 & 7 & 34 & 8 & 42 & 132 & 92670 & $\begin{array}{l}\text { Transcription factor, regulator the } \\
\text { hypoxia in cells }\end{array}$ \\
\hline 11 & $\begin{array}{l}\text { Peroxisome proliferator- } \\
\text { activated receptors D }\end{array}$ & 125 & 28 & 6 & 34 & 9 & 40 & 127 & 49903 & $\begin{array}{l}\text { Nuclear hormone receptor, integrator } \\
\text { of transcription repression and nuclear } \\
\text { receptor signaling }\end{array}$ \\
\hline 12 & $\begin{array}{l}\text { Voltage-dependent } \\
\text { calcium channels } 1 \mathrm{D} \\
\text { and } 1 \mathrm{C}\end{array}$ & 26 & 29 & 5 & 32 & 7 & 22 & 47 & 245141 & $\begin{array}{l}\text { The regulator of hormone and } \\
\text { neurotransmitter release, muscle } \\
\text { contraction, cellular functions }\end{array}$ \\
\hline 13 & $\begin{array}{l}\text { Nitric oxide synthase, } \\
\text { endothelial }\end{array}$ & 147 & 39 & 5 & 41 & 9 & 45 & 132 & 133289 & $\begin{array}{l}\text { Vascular tone, cellular proliferation, } \\
\text { leukocyte adhesion, platelet } \\
\text { aggregation }\end{array}$ \\
\hline
\end{tabular}

$\mathrm{MW}^{*}$ - molecular weight (Da); Groop 2a $\mathrm{a}^{1}$, Group 2 $\mathrm{b}^{2}$, Group $2 \mathrm{c}^{3}$ - after 3 years of personalized hypotensive drug therapy 
angiotensin-aldosterone system), PPARs, WNT (Wg/Int), NOTCH signaling pathways, mitochondria and ROS signaling pathways (electron-transport chain signaling, stress-induced protein kinases: JNK and MST-1), and genome surveillance pathways (tumor suppressors and antagonistic pleiotropy).

Each protein molecule in the functional group interacts with other protein molecules. For example, the molecular interactions of hypoxia inducible factor 1 , alpha subunit (HIF-1alpha) are presented in Fig.1. Serum HIF-1alpha concentration rose in ISH patients, and was most pronounced in Group 2c.

\section{Conclusion}

We identified potentially new biomarkers of cardiovascular aging that could help in developing a noninvasive, serum-based diagnostic test. This study is the first step in the development of a new system for creation of personalized hypotensive therapy. The dynamics in the proteome-map of blood serum in ISH patients revealed the molecular mechanism of neuro-, cadio- and vascular protective effects of amlodipine and valsartan, as a geroprotective mode of drug action.

\section{Competing interests}

The authors declare that they have no competing interests.

\section{References}

1. Nielsen WB, Vestbo J, Jensen GB. Isolated systolic hypertension as a major risk factor for stroke and myocardial infarction and an unexploited source of cardiovascular prevention: a prospective population-based study. J Hum Hypertens. 1995; 9(3):175-80.

2. Boutouyrie P, Tropeano A, Asmar R, Gautier I, Benetos A, Lacolley $\mathrm{P}$, at al. Aortic stiffness is an independent predictor of primary coronary events in hypertensive patients: a longitudinal study. Hypertension. 2002. 39(1):10-5.

3. McEniery CM1, Yasmin, Hall IR, Qasem A, Wilkinson IB,

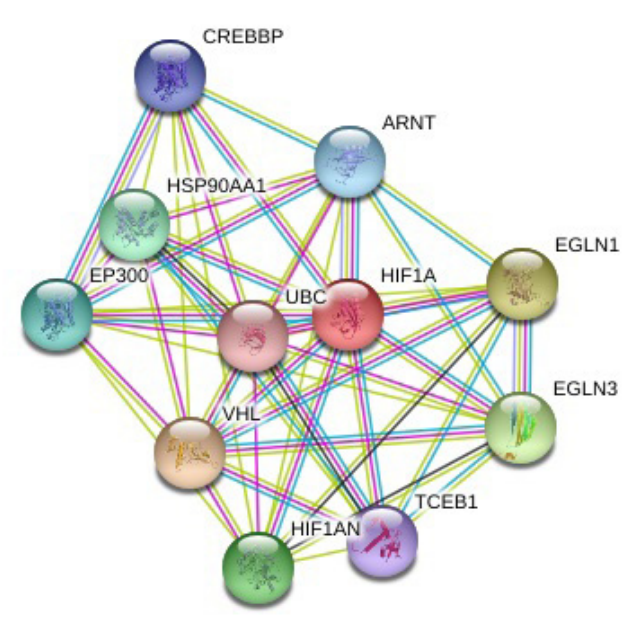

Fig. 1. Molecular interactions of HIF-1alpha (STRING 10.0 database)

VHL-von Hippel-Lindau tumor suppressor, E3 ubiquitin protein ligase; EGLN1-egl nine homolog 1; EGLN3 - egl nine homolog 3 (C. elegans); HIF1ANhypoxia inducible factor 1, alpha subunit inhibitor; HSP90AA1-heat shock protein $90 \mathrm{kDa}$ alpha (cytosolic), class A member 1; EP300-E1A binding protein p300; ARNT-aryl hydrocarbon receptor nuclear translocator; CREBBP-CREB binding protein; TCEB1-transcription elongation factor $B$ (SIII), polypeptide 1; UBC-ubiquitin $C$.

Cockcroft JR. Normal vascular aging: differential effects on wave reflection and aortic pulse wave velocity: the AngloCardiff Collaborative Trial (ACCT). J Am Coll Cardiol. 2005; 46(9):1753-1760.

4. Mancia G, Fagard R, Narkiewicz K, Redon J, Zanchetti A, Böhm M, et al. $2013 \mathrm{ESH} / \mathrm{ESC}$ guidelines for the management of arterial hypertension: the Task Force for the Management of Arterial Hypertension of the European Society of Hypertension (ESH) and of the European Society of Cardiology (ESC). Eur Heart J. 2013;34(28):2159-219. 